\title{
Contributions on the Sensorial, Physico-Chemical and Nutritional Characterization of Meat in Flemish Giant Rabbit Breed
}

\author{
GABRIELA FRUNZA ${ }^{1}$, DANIEL SIMEANU1*, IOAN MIRCEA POP1*, PAUL CORNELIU BOISTEANU ${ }^{1}$, MARCELA STEFAN ${ }^{2}$ \\ IUniversity of Agricultural Sciences and Veterinary Medicine of lasi, 3 Mihail Sadoveanu Alley 700490, lasi, Romania \\ ZUniversity of Economic Studies of Bucharest, 6 Romana Sq., 010374, Bucharest, Romania
}

\begin{abstract}
The purpose of this study was to investigate the sensorial, physico-chemical and nutritional traits of the meat in Flemish Giant rabbit breed. The biological material comprised 75 rabbits (25 males and 50 females), slaughtered at the age of 11 months, at an average carcass weight of $11.5 \mathrm{~kg}$. Samples of the following muscle groups were taken: Longissimus dorsi (LD), Triceps brachii (TB) and Semimembranosus (SM) and were kept at $2^{\circ} \mathrm{C}$. Two hundred and twenty-five samples were analyzed to assess the physico-chemical peculiarities ( $\mathrm{pH}$ measurements at 24- and $48 \mathrm{~h}$ post-slaughter; water, proteins, lipids, fatty acids and crude ash assessments). Another 225 samples ( 75 for each muscle group) were used as well to investigate the sensorial properties. The results issued from sensorial analysis were close as score among the three muscle groups studied. The $\mathrm{pH}$ value was higher in TB muscles. LD muscles from males had the highest protein content (21.70\%), TB muscles of females had the highest proportion of lipids (2.65\%), while the fatty acid content was higher in females for all analyzed muscles. Except for muscular content in some fatty acids, variance analysis highlighted not significant differences between genders for the studied characters.
\end{abstract}

Keywords: rabbit meat, fatty acids, proteins, lipids

The rabbit, due to its production and reproduction capacities, higher to other species, can make an important contribution to the fight, worldwide, for providing animal proteins in human diets [1-4]. Global rabbitmeat production has steadily increased throughout 2010-2016, from $1,224,186$ to $1,428,085$ tones [4]. The production areas are mainly Asia, Europe, America and Africa $[3,6]$. Meat consumption is continuously increasing worldwide, due to the observed trend to buy lean meats, poor in cholesterol and with high protein and unsaturated fatty acids contents.

Rabbit meat, according to current research reports published worldwide [1-3, 6-67], has excellent nutritional properties. It is rich in protein (18.6-22.4 g/100 g) with high biological value through the essential amino acid content, low in fat $(1.8-8.8 \mathrm{~g} / 100 \mathrm{~g})$, cholesterol $(47-61 \mathrm{mg} / 100 \mathrm{~g})$, $\mathrm{Na}(37-47 \mathrm{mg} / 100 \mathrm{~g})$. It is also recommended in hypertensive people diets [24-36], as well as in people affected by gout, due to the low purine content and the lack of uric acid [53]. It is rich in K (428-431 mg/100 g), P $(222-237 \mathrm{mg} / 100 \mathrm{~g}), \mathrm{Mg}(27 \mathrm{mg} / 100 \mathrm{~g}), \mathrm{Fe}(5.56 \mathrm{mg} / 15.0$ $\mathrm{g} / 100 \mathrm{~g}$ ), B complex vitamins and has a favorable high unsaturated fatty acids profile, with high $\omega 6 / \omega 3$ ratio [24$36,52,62,64-66]$. Therefore, it is considered a natural functional food [35]. These nutritional properties satisfy the desire of modern consumers to have a healthy lifestyle $[1-3,6-9,12-66]$. Rabbit meat fits perfectly to these requirements; the main feature in its assessment is the increased content of monounsaturated and polyunsaturated fatty acids [63-65] that are directly involved in human health [68-85].

In rabbit meat, sensorial properties are some of the main criteria that influence consumer choice [ $1,2,42,44]$, specifically the tenderness and the flavor. Fresh rabbitmeat has a specific flavor, the color is pale pink, and becomes white during boiling, the same as the poultry $[37,67]$.

The rabbitrepresents a good model for biological studies due to the short interval between generations and to the low cost of producing their carcasses [41-44, 53-55].
Aspects regarding the quality of rabbit meat are being studied intensively at the level of average size breeds [ 1-3, 6-66] but for the Flemish giant breed (which can be used as an improver of the meatyield in other breeds) insufficient data has been reported.

Sensorial, physico-chemical and nutritional characterization of Flemish giant rabbit meat contributes to enrich the knowledge base for possible crossbreeding with average size breeds. However, additional studies are needed to be able to fully recommend this breed as an improver of lower performing rabbit breeds.

\section{Experimental part}

Materials and methods

Biological material comprised 75 rabbits $(25$ males and 50 females), slaughtered at the age of 11 months, with an average carcass weight of $11.5 \mathrm{~kg}$. Meat sampling was carried on right after slaughter, using three different muscular groups (LD-Longissimus dorsi, SMSemimembranosus and TB -Triceps brachii muscles); they have been chosen due to their different physical-chemical properties and to the different metabolic types. It has been attempted to cover, as well, the main anatomical regions of the carcasses (back -LD, hind leg-SM, foreleg -TB).

In order to assess the physical-chemical traits (measurement of $\mathrm{pH}$ at 24 and $48 \mathrm{~h}$ post-slaughter, assessment of water, proteins, lipids, fatty acids and ash contents), the muscle groups on the right side of the carcass were used, summarizing 225 samples ( 75 for each muscle group). They were preliminary fine grinded and homogenized using an electric shredder. Sensory analyses were performed by tasting, using the muscle groups on the left side of the carcasses - 225 samples - individually packaged, vacuumed and then prepared for one hour at a constant temperature of $80^{\circ} \mathrm{C}$ in a water bath. After cooling, the samples were cut and distributed so that there are no differences of their location at the level of each muscle, then randomly assigned to 36 tasters, trained in advance. 
The assessment sheets of the sensory characteristics were filled in using a five-point hedonic scale (scores from 1 to 5), in which 1 represented the not favorable features, while 5 points indicated the characteristics which fully satisfied the requirements of the tasters. For example: the extremely pale color was noted with 1 , while the intense red color was noted with 5; global assessment was scored with 1 for unacceptable meat, with 2 points for acceptable meat, with 3 points for good meat, with 4 points for very good meat and with 5 points for exceptional meat.

Meat $p H$ value was measured was used digital $\mathrm{pH}$ meter Hanna Electronics, type 212 , on chilled samples $\left(2^{\circ} \mathrm{C}\right)$ for two consecutive days after slaughter. The water, protein and lipid content was determined using the Food Check (Near Infrared Spectrophotometer); crude ash content assessed by calcination (at $550^{\circ} \mathrm{C}$ for 16 hours after a preliminary carbonization) [86] and the energy value was determined by calculation using conventional formulas. Assessment of fatty acids content was performed by NIRS technology using the FOSS 6500 spectrophotometer. The freshly ground samples were placed in sterile Petri dishes, weighed, then lyophilized at $-110^{\circ} \mathrm{C}$ for $24 \mathrm{~h}$, using the CoolSafe ${ }^{T M}$, SCANVAC lyophilizer, weighed again and then vacuumed (in special bags, labelled appropriately) and stored in a freezer at a temperature of $-80^{\circ} \mathrm{C}$ until the moment of their analysis. Were determined the following saturated fatty acids (SFA): C14:0 (myristic acid), C15:0 (pentadecanoic acid), C16:0 (palmitic acid) C17:0 (heptadecanoic acid) and C18:0 (stearic acid). Among the monounsaturated fatty acids (MUFA, $\omega 7$ and $\omega 9$ ) there were assessed: C16:1n-7 (palmitoleic acid), C18:1n-7 (vaccenic acid cis isomer of oleic acid) and C18:1n-9 (oleic acid); a total of nine polyunsaturated fatty acids (PUFA, $\omega 3$ and $\omega 6)$ were also assessed: C18:2n-6 (linoleic), C18:3n-3 (linolenic), C20:2n-6 (eicosadienoic), C20:3n-6 (eicosatrienoic), C20:4n-6 (arachidonic), C20:5n-3 (eicosapentaenoic or EPA), C22: 4n-6 (docosatetraenoic), C22: $5 n-3$ (docosapentaenoic or DPA) and C22: $6 n-3$ (docosahexaenoic or DHA). All the achieved results were statistically processed through the main description computation and analysis of variance test (Anova single factor), using the GraphPad Prism 7.0 software.
Following sensory investigation for LD muscles, it can be noted a higher average score for males compared to females (3.35 for global appreciation, 3.4 for smell, 3.65 for taste). By applying the test for analysis of variance (ANOVA) at the level of LD muscles insignificant gender differences were noted (table 1). The intensity of the flavor for SM muscles had the highest score in males (3.56), while the color had the weakest one (2.12 on average for both females and males), due to the white meat chromatic characteristics. Analysis of variance applied on SM muscles scores comparisons between females and males, revealed not significant differences $(P>0.05)$ for five parameters: color, fibrous appearance, taste, juiciness and global appreciation. Significant differences $((P<0.01)$ were found for flavor and tenderness, distinguished significant differences for smell $(P<0.01)$, and very significant differences $(P<0.001)$ for the flavor intensity. In TB muscles, it could be noted an average score generally higher for males compared to females (3.25 for global appreciation, 3.06 for smell, 3.65 for taste), but the exception of juiciness and the tenderness, that had higher values in females (2.81 for juiciness and 3.11 for tenderness). The statistical analysis showed not significant differences between genders.

For average sized breeds, in some studies [44] following sensory appreciation, the meat has accumulated a higher score for fibrousness (4.5) and juiciness (3.6). However, the biological material used in such studies was younger; hence the higher water content, as well as the lower thickness of muscle fibers, compared to our findings.

The results of the sensory analysis presented in literature are uneven, due to the multiple factors involved, such as the heterogeneity of the biological material, differences in tasters training and applied assessment methods by each group of researchers, from each region, country etc. [1, 2, $20,29,51,58,61]$. Hence, we have not found in our literature survey exhaustive studies on sensory and physicalchemical investigations on the meat of Flemish rabbit giant breed, we decided to carry on this study.

Related to the $\mathrm{pH}$ value of the meat, the variance analysis showed not significant differences between genders. Higher values were observed in TB muscles (on average

Table 1

SENSORIAL SCORES OF LONGISSIMUS DORSI, SEMIMEMBRANOSUS AND TRICEPS BRACHII MUSCLES

\begin{tabular}{|c|c|c|c|c|c|c|c|c|c|c|}
\hline \multirow[b]{2}{*}{ Traits } & \multirow[b]{2}{*}{$\mathbf{M} / \mathbf{F}$} & \multicolumn{3}{|c|}{ LD } & \multicolumn{3}{|c|}{ SM } & \multicolumn{3}{|c|}{ TB } \\
\hline & & $\bar{x} \pm s_{\bar{x}}$ & $V \%$ & Anova & $\bar{x} \pm s_{\bar{x}}$ & $V \%$ & Anova & $\bar{x} \pm s_{\bar{x}}$ & $V \%$ & Anova \\
\hline \multirow{2}{*}{ Color } & $\mathrm{M}$ & $1.85 \pm 0.11$ & 26.45 & \multirow{2}{*}{$\begin{array}{c}\text { n.s. } \\
p=0.261\end{array}$} & $2.11=0.05$ & 15.09 & \multirow{2}{*}{$\begin{array}{c}\text { n.s. } \\
\mathrm{p}=0.879\end{array}$} & $2.13=0.12$ & 16.07 & \multirow{2}{*}{$\begin{array}{c}\text { n.s. } \\
\mathrm{p}=0.121\end{array}$} \\
\hline & $F$ & $2.02 \pm 0.07$ & 16.22 & & $2.13 \pm 0.09$ & 27.22 & & $1.94=0.18$ & 35.10 & \\
\hline \multirow{2}{*}{ ibrous appearance } & $\mathrm{M}$ & $2.60=0.19$ & 33.95 & \multirow{2}{*}{$\begin{array}{c}\text { n.s. } \\
\mathrm{p}=0.778\end{array}$} & $3.00=0.11$ & 22.54 & \multirow{2}{*}{$\begin{array}{c}\text { n.s. } \\
\mathrm{p}=0.040\end{array}$} & $2.81=0.22$ & 29.66 & \multirow{2}{*}{$\begin{array}{c}\text { n.s. } \\
\mathrm{p}=0.185\end{array}$} \\
\hline & $F$ & $2.53 \pm 0.18$ & 31.13 & & $2.67 \pm 0.10$ & 25.36 & & $2.44 \pm 0.13$ & 29.84 & \\
\hline \multirow{2}{*}{ Smell } & $\mathrm{M}$ & $3.40=0.21$ & 27.66 & \multirow{2}{*}{$\begin{array}{c}\text { n.s. } \\
\mathrm{p}=0.867\end{array}$} & $3.33=0.14$ & 24.84 & \multirow{2}{*}{$\begin{array}{c}* * \\
\mathrm{p}=0.005\end{array}$} & $3.06 \pm 0.26$ & 32.58 & \multirow{2}{*}{$\begin{array}{c}\text { n.s. } \\
\mathrm{p}=0.347\end{array}$} \\
\hline & $\mathrm{F}$ & $3.35 \pm 0.20$ & 27.86 & & $2.78 \pm 0.13$ & 28.69 & & $2.50=0.17$ & 32.66 & \\
\hline \multirow[b]{2}{*}{ Taste } & M & $3.65=0.18$ & 22.27 & \multirow{2}{*}{$\begin{array}{c}\text { n.s. } \\
\mathrm{p}=0.389\end{array}$} & $3.33 \pm 0.11$ & 20.28 & \multirow{2}{*}{$\begin{array}{c}\text { n.s. } \\
\mathrm{p}=0.190\end{array}$} & $3.19=0.09$ & 28.57 & \multirow{2}{*}{$\begin{array}{c}\text { n.s. } \\
\mathrm{p}=0.132\end{array}$} \\
\hline & $\mathrm{F}$ & $3.40=0.22$ & 29.26 & & $3.16 \pm 0.12$ & 24.03 & & $2.94 \pm 0.16$ & 31.62 & \\
\hline \multirow{2}{*}{ The flavor } & $\mathrm{M}$ & $3.40=0.18$ & 24.14 & \multirow{2}{*}{$\begin{array}{c}\text { n.s. } \\
p=0.559\end{array}$} & $3.21=0.15$ & 14.04 & \multirow{2}{*}{$\stackrel{*}{*}=0.999$} & $3.15=0.23$ & 25.80 & \multirow{2}{*}{$\begin{array}{c}\text { n.s. } \\
\mathrm{p}=0.453\end{array}$} \\
\hline & F & $3.25 \pm 0.18$ & 24.19 & & $3.14=0.13$ & 18.02 & & $3.13=0.08$ & 25.80 & \\
\hline \multirow{2}{*}{$\begin{array}{c}\text { Flavor } \\
\text { intensity }\end{array}$} & M & $2.95=0.17$ & 25.73 & \multirow{2}{*}{$\begin{array}{c}\text { n.s. } \\
\mathrm{p}=0.426\end{array}$} & $3.56 \pm 0.14$ & 23.72 & \multirow{2}{*}{$\begin{array}{c}* * * \\
p=5.785\end{array}$} & $3.63=0.14$ & 24.42 & \multirow{2}{*}{$\begin{array}{c}\text { n.s. } \\
p=0.103\end{array}$} \\
\hline & $\mathrm{F}$ & $3.15 \pm 0.18$ & 25.80 & & $2.67 \pm 0.08$ & 17.93 & & $3.13 \pm 0.026$ & 25.80 & \\
\hline \multirow{2}{*}{ Juiciness } & $\mathrm{M}$ & $3.00=0.24$ & 35.87 & \multirow{2}{*}{$\begin{array}{c}\text { n.s. } \\
p=0.294\end{array}$} & $2.59 \pm 0.18$ & 42.29 & \multirow{2}{*}{$\begin{array}{c}\text { n.s. } \\
\mathrm{p}=0.133\end{array}$} & $2.44 \pm 0.21$ & 44.86 & \multirow{2}{*}{$\begin{array}{c}\text { n.s. } \\
\mathrm{p}=0.215\end{array}$} \\
\hline & $F$ & $2.70=0.15$ & 24.33 & & $2.89 \pm 0.13$ & 25.87 & & $2.81=0.07$ & 26.67 & \\
\hline \multirow{2}{*}{ Tendemess } & $\mathrm{M}$ & $3.30 \pm 0.22$ & 29.68 & & $2.78 \pm 0.17$ & 37.62 & * & $2.69 \pm 0.24$ & 40.12 & \\
\hline & F & $3.00=0.15$ & 21.63 & $\mathrm{p}=0$. & $3.33 \pm 0.14$ & 24.84 & $\mathrm{p}=0.015$ & $3.11=0.19$ & 26.36 & $=0243$ \\
\hline & $\mathrm{M}$ & $3.35 \pm 0.23$ & 31.04 & & $3.33 \pm 0.16$ & 28.69 & & $3.25 \pm 0.22$ & 30.77 & \\
\hline essm & F & $3.25 \pm 0.18$ & 24.19 & $\mathrm{p}=$ & $3.11 \pm 0.13$ & 24.03 & $\mathrm{p}=0$ & $3.00 \pm 0.17$ & 24.34 & \\
\hline
\end{tabular}

Note: M/F $=$ Males/Females; n.s. $=p>0.05 ;^{*}=0.05>p>0.01 ; * *=0.01>p>0.001 ;{ }^{* 8 *}=0.001>p$. 
above $6.01 \mathrm{UpH}$ for females and males, at $24 \mathrm{~h}$ post slaughtering) compared to the others muscle groups which had $\mathrm{pH}$ values below 5.81, probably based on the different metabolic type (table 2).

Table 2

THE pH OF RABBIT MEAT AT 24h AND 48h POST SLAUGHTERING (UpH)

\begin{tabular}{|c|c|c|c|c|c|}
\hline Muscles & Period & $\mathrm{M} / \mathrm{F}$ & $\bar{x} \pm s_{\bar{x}}$ & V\% & Anova \\
\hline \multirow{4}{*}{ LD } & \multirow{2}{*}{$24 \mathrm{~h}$} & $\mathrm{M}$ & $5.715 \pm 0.053$ & 2.64 & $\mathrm{p}=0.319$ \\
\hline & & F & $5.732 \pm 0.072$ & 3.08 & n.s. \\
\hline & \multirow[b]{2}{*}{$48 \mathrm{~h}$} & $\mathrm{M}$ & $5.728 \pm 0.061$ & 3.01 & $\mathrm{p}=0.286$ \\
\hline & & $F$ & $5.792 \pm 0.074$ & 3.12 & n.s. \\
\hline \multirow{4}{*}{ SM } & \multirow{2}{*}{$24 \mathrm{~h}$} & $\mathrm{M}$ & $5.786 \pm 0.041$ & 1.98 & $\mathrm{p}=0.124$ \\
\hline & & $F$ & $5.805 \pm 0.063$ & 2.66 & n.s. \\
\hline & \multirow{2}{*}{$48 \mathrm{~h}$} & $\mathrm{M}$ & $5.765 \pm 0.053$ & 2.65 & $\mathrm{p}=0.233$ \\
\hline & & $F$ & $5.870 \pm 0.057$ & 2.37 & n.s. \\
\hline \multirow{4}{*}{ TB } & \multirow{2}{*}{$24 \mathrm{~h}$} & $\mathrm{M}$ & $6.018 \pm 0.030$ & 1.48 & $\mathrm{p}=0.241$ \\
\hline & & $F$ & $5.985 \pm 0.054$ & 2.21 & n.s. \\
\hline & \multirow{2}{*}{$48 \mathrm{~h}$} & $M$ & $6.059 \pm 0.029$ & 1.43 & $\mathrm{p}=0.854$ \\
\hline & & $F$ & $6.115 \pm 0.041$ & 1.67 & n.s. \\
\hline
\end{tabular}

Note: $\mathrm{M} / \mathrm{F}=$ Males $/$ Females; n.s. $=\mathrm{p}>0.05 ;{ }^{*}=0.05>\mathrm{p}>0.01$; $* *=0.01>p>0.001 ; * * *=0.001>p$.

Different authors reported high glycolytic activity in LD and high oxidative activity in SM (slow-oxidative fibers type) $[10,11,41-43]$. The $\mathrm{pH}$ values found were close to those analyzed in average sized breeds [43] in LD muscles and lower than those, in SM muscles. No pH values were found in literature for TB muscles, to run a comparison with our findings.

The assessment of the chemical composition of rabbit meat comprised the determination of proteins, lipids, water and mineral substances (crude ash). Regarding the proteins content, the highest values were observed in males, in LD muscles, with an average of $21.71 \mathrm{~g} / 100 \mathrm{~g}$. For the other muscle groups the mean values were close for females and males, while statistical differences were insignificant (table 3). Similar proteins content was also reported in other articles for rabbit meat of average sized breeds [1, 17-20, 25-36, 40-43]. The proteins level varies relatedly to the carcass part, between $18.6 \mathrm{~g} / 100 \mathrm{~g}$ in forelegs and $22.4 \mathrm{~g} / 100 \mathrm{~g}$ in LD muscles [24-36, 48]. The

Table 3

THE PROTEIN CONTENT $(\mathrm{g} / 100 \mathrm{~g})$ OF RABBIT MEAT

\begin{tabular}{|c|c|c|c|c|}
\hline Muscles & Gender & $\bar{x} \pm s_{\bar{x}}$ & $V \%$ & Anova \\
\hline \multirow{2}{*}{ SM } & Females & $21.63 \pm 0.19$ & 1.48 & \multirow{2}{*}{$\begin{array}{c}\mathrm{p}=0.686 \\
\text { n.s. }\end{array}$} \\
\hline & Males & $21.50 \pm 0.32$ & 2.59 & \\
\hline \multirow{2}{*}{ LD } & Females & $21.53 \pm 0.58$ & 4.72 & \multirow{2}{*}{$\begin{array}{c}\mathrm{p}=0.576 \\
\text { n.s. }\end{array}$} \\
\hline & Males & $21.70 \pm 0.23$ & 1.84 & \\
\hline \multirow{2}{*}{ TB } & Females & $21.48 \pm 0.45$ & 0.98 & \multirow{2}{*}{$\begin{array}{c}\mathrm{p}=0.486 \\
\text { n.s. }\end{array}$} \\
\hline & Males & $21.55 \pm 0.05$ & 0.34 & \\
\hline
\end{tabular}

proportion of water and protein is higher in younger rabbits, and the amount of lipids is lower [29,35,40].

The highest amount of lipids was found in TB muscles ( $2.65 \mathrm{~g} / 100 \mathrm{~g}$ for females and $2.57 \mathrm{~g} / 100 \mathrm{~g}$ for males), and the lowest was observed in LD muscles $(2.13 \mathrm{~g} / 100 \mathrm{~g}$ for males and 2.32 for females). Variance analysis revealed insignificant differences between genders (table 4).

The assessed fat content was relatively close to the results found in the literature [21-24, 36, 53-55]. Pla M. et al., 2004 [48], found in LD muscle an average of $1.2 \mathrm{~g} / 100$ $\mathrm{g}$ lipids (limits 0.62-1.94\%) and in the hind legs meat, an average level of $3.03 \mathrm{~g} / 100 \mathrm{~g}$ (limits of 1.32-6.10 g/100 g).
Table 4

THE LIPIDS CONTENT ( $\mathrm{g} / 100 \mathrm{~g}$ ) OF RABBIT MEAT

\begin{tabular}{|c|c|c|c|c|}
\hline Muscles & Gender & $\bar{x} \pm s_{\bar{x}}$ & $V \%$ & Anova \\
\hline \multirow{2}{*}{ SM } & Females & $2.45 \pm 0.64$ & 5.01 & $\mathrm{p}=0.852$ \\
\hline & Males & $2.56 \pm 1.46$ & 3.84 & n.s. \\
\hline \multirow{2}{*}{ LD } & Females & $2.32 \pm 1.20$ & 3.16 & $\mathrm{p}=0.659$ \\
\hline & Males & $2.13 \pm 0.09$ & 4.75 & n.s. \\
\hline \multirow{2}{*}{ TB } & Females & $2.65 \pm 0.99$ & 25.89 & $p=0.548$ \\
\hline & Males & $2.57 \pm 2.05$ & 8.32 & n.s. \\
\hline
\end{tabular}

Slightly lower values have been reported by other authors for average sized rabbit breed, while the age at slaughter was much lower (approximately three months) [40-43, 50-55].

The highest water content was found in LD and SM muscles (about $75 \mathrm{~g} / 100 \mathrm{~g}$ in both genders), while the lowest ones in TB muscles (an average of $71.2 \mathrm{~g} / 100 \mathrm{~g}$ for both genders). The differences were not significant statistically (table 5). The achieved values were places within the limits obtained by other authors on rabbit meat of average sized breeds, from $69.7 \mathrm{~g} / 100 \mathrm{~g}$ in limbs muscles

Table 5

THE WATER CONTENT $(\mathrm{g} / 100 \mathrm{~g})$ OF RABBIT MEAT

\begin{tabular}{|c|c|c|c|c|}
\hline Muscles & Gender & $\bar{x} \pm s_{\bar{x}}$ & $V \%$ & Anova \\
\hline \multirow[b]{2}{*}{ SM } & Females & $75.0 \pm 0.71$ & 1.64 & \multirow{2}{*}{$\begin{array}{c}\mathrm{p}=0.821 \\
\text { n.s. }\end{array}$} \\
\hline & Males & $74.7 \pm 1.13$ & 2.61 & \\
\hline \multirow{2}{*}{ LD } & Females & $75.03 \pm 0.62$ & 1.43 & \multirow{2}{*}{$\begin{array}{c}\mathrm{p}=0.902 \\
\text { n.s. }\end{array}$} \\
\hline & Males & $74.9 \pm 0.81$ & 1.88 & \\
\hline \multirow{2}{*}{ TB } & Females & $72.16 \pm 1.41$ & 3.38 & \multirow{2}{*}{$\begin{array}{c}\mathrm{p}=0.531 \\
\text { n.s. }\end{array}$} \\
\hline & Males & $70.21 \pm 1.6$ & 3.22 & \\
\hline
\end{tabular}

[12-24, $29,35,53-55]$ to $75.3 \mathrm{~g} / 100 \mathrm{~g}$ water in LD muscles [40].

The ash content for the analyzed muscle groups was relatively close, with higher average values for TB muscles (1.231\% for males). Not significant differences were observed between genders (table 6). Quite similar values of the ash content (1.214\%), were found in average sized

Table 6

THE CRUDE ASH CONTENT ( $\mathrm{g} / 100 \mathrm{~g}$ ) OF RABBIT MEAT

\begin{tabular}{|c|c|c|c|c|}
\hline Muscles & Gender & $\bar{x} \pm s_{\bar{x}}$ & $V \%$ & Anova \\
\hline \multirow{2}{*}{ SM } & Females & $1.198 \pm 0.11$ & 0.25 & $\mathrm{p}=0.573$ \\
\hline & Males & $1.149 \pm 0.45$ & 0.3 & n.s. \\
\hline \multirow[b]{2}{*}{ LD } & Females & $1.203 \pm 0.10$ & 0.14 & $\mathrm{p}=0.214$ \\
\hline & Males & $1.220 \pm 0.26$ & 1.08 & n.s. \\
\hline \multirow{2}{*}{ TB } & Females & $1.212 \pm 0.06$ & 1.19 & $\mathrm{p}=0.431$ \\
\hline & Males & $1.231 \pm 0.19$ & 1.16 & n.s. \\
\hline
\end{tabular}

rabbits breeds in Spain [8, 52, 62], Italy [29, 35], Hungary [49], France [17, 20] etc.

The highest level of gross energy (GE), provided to consumers through meat intake was found in TB muscles $(168.5 \mathrm{kcal} / 100 \mathrm{~g})$. For the other muscle groups, the calculated values were lower but close (144-147 kcal/100 g). Differences between genders were not statistically significant (table 7).

Other authors have reported gross energy value close to these presented in our study, with limits ranging from $144.26 \mathrm{kcal} / 100 \mathrm{~g}$ in LD muscles to $215.07 \mathrm{kcal} / 100 \mathrm{~g}$ in muscles of the foreleg [35]. Rabbit meat provides moderate energy value, relying primarily on its high protein content. 
Table 7

THE GROSS ENERGY VALUE OF RABBIT MEAT (Kcal/100 g)

\begin{tabular}{|c|c|c|c|c|}
\hline Muscles & Gender & $\bar{x} \pm s_{\bar{x}}$ & $V \%$ & Anova \\
\hline \multirow{2}{*}{ SM } & Females & $143.81 \pm 1.32$ & 5.23 & \multirow{2}{*}{$\begin{array}{c}\mathrm{p}=0.354 \\
\text { n.s. }\end{array}$} \\
\hline & Males & $147.13 \pm 0.15$ & 4.73 & \\
\hline \multirow{2}{*}{ LD } & Females & $144.92 \pm 0.65$ & 8.15 & \multirow{2}{*}{$\begin{array}{c}\mathrm{p}=0.126 \\
\text { n.s. }\end{array}$} \\
\hline & Males & $144.24 \pm 0.76$ & 9.18 & \\
\hline \multirow{2}{*}{ TB } & Females & $161.94 \pm 0.48$ & 3.13 & \multirow{2}{*}{$\begin{array}{c}\mathrm{p}=0.349 \\
\text { n.s. }\end{array}$} \\
\hline & Males & $168.56 \pm 1.61$ & 2.62 & \\
\hline
\end{tabular}

The average fatty acid content in the three muscle groups showed predominantly higher values for females (table 8). For LD muscles, the highest value of PUFA was highlighted at the level of linoleic acid $(257.23 \mathrm{mg} / 100 \mathrm{~g}$ meat). For MUFA, the most significant quantity was found for oleic acid, $359.09 \mathrm{mg} / 100 \mathrm{~g}$ of meat, followed by palmitoleic acid with $61.82 \mathrm{mg} / 100 \mathrm{~g}$ of meat. The low est value was observed for vaccenic acid, $18.19 \mathrm{mg} / 100 \mathrm{~g}$ of meat.

Among the saturated fatty acids, the highest value was found for the palmitic acid, $408.66 \mathrm{mg} / 100 \mathrm{~g}$ of meat, also for females, while for males the determined quantity was almost halved ( $217.83 \mathrm{mg} / 100 \mathrm{~g}$ meat). The content in fatty acids for LD muscles, by gender, showed significant differences in heptadecanoic and stearic SFAs, for oleic acid, MUFA and for linoleic and arachidonic PUFAs; distinguished significant differences have been highlighted only for docosatetraenoic fatty acid; for the other fatty acids, the statistical differences were insignificant.

The content in fatty acids of SM muscles had the highest values for females; thus, for SFA, a higher value for palmitic acid ( $613.57 \mathrm{mg} / 100 \mathrm{~g}$ meat) was observed, and less than half was found in males ( $271.82 \mathrm{mg} / 100 \mathrm{~g}$ meat); for MUFA content, the highest value was also highlighted for females, for oleic acid, $592.60 \mathrm{mg} / 100 \mathrm{~g}$ of meat, followed by palmitoleic acid, $105.74 \mathrm{mg} / 100 \mathrm{~g}$ of meat. In the case of
PUFA, the highest amount was observed in females, as well, for those fatty acids that form vitamin $F$ (linoleic acid, $393.42 \mathrm{mg} / 100 \mathrm{~g}$ meat, arachidonic acid, $54.69 \mathrm{mg} / 100 \mathrm{~g}$ meat and linolenic acid, $39.72 \mathrm{mg} / 100 \mathrm{~g}$ meat). Regarding the statistical significance of the fatty acid content for SM muscles, by gender, very significant differences were observed for all SFAs (myristic, pentadecanoic, palmitic, heptadecanoic, stearic), for MUFA (palmitoleic, vaccenic, oleic) and PUFA (docosatetraenoic); not significant differences were observed only for some PUFAs: eicosapentaenoic acid and docosahexaenoic acid.

For TB muscles, the average fatty acid content was sometimes double for females, compared to males; thus, the highest value was observed for oleic acid, MUFA, 949.18 $\mathrm{mg} / 100 \mathrm{~g}$ of meat, followed by the palmitic acid, SFA, $879.08 \mathrm{mg} / 100 \mathrm{~g}$ of meat and by the linoleic one, PUFA, $680.14 \mathrm{mg} / 100 \mathrm{~g}$ of meat. Relatively large amounts were also recorded for palmitoleic acid, MUFA, $173.22 \mathrm{mg} / 100$ g meat, followed by PUFAs (linolenic, $71.52 \mathrm{mg} / 100 \mathrm{~g}$ meat and arachidonic, $53.69 \mathrm{mg} / 100 \mathrm{~g}$ meat). Following the statistical significance of the differences on the fatty acid content for TB muscles, very significant differences were observed for all SFAs, MUFA and for three other PUFAs: linoleic acid, linolenic acid and eicosadienoic acid; distinguished significant differences were noticed for docosatetraenoic acid and insignificant differences ones for PUFA: eicosatrienoic, arachidonic, EPA, DPA and DHA.

The results regarding the content in fatty acids of $L D$ muscles samples, were relatively close to those observed in other research reports, who followed the same parameters on rabbit meat belonging to the average sized breeds (Californian, Neo Zeelandez) [6-9, 25-36, 53-55].

Recommended ratio for PUFA: SFA is 0.45 or higher [5, 48], an aspect that is also observed in all the analyzed muscle groups from this study (ranging from 0.664 for females, in SM muscles to 1,088 for males, in the TB muscles), in agreement with other studies [7-9, 64-66].

Table 8

THE FATTY ACIDS CONTENT (mg/100 g MEAT) FOR LD, SM AND TB MUSCLES

\begin{tabular}{|c|c|c|c|c|c|c|c|c|c|c|c|}
\hline \multirow{2}{*}{\multicolumn{2}{|c|}{ Fatty acids }} & \multirow{4}{*}{\begin{tabular}{|l}
$\mathbf{M} / \mathbf{F}$ \\
$\mathrm{M}$ \\
$\mathrm{F}$ \\
\end{tabular}} & \multicolumn{3}{|c|}{ LD } & \multicolumn{3}{|c|}{ SM } & \multicolumn{3}{|c|}{ TB } \\
\hline & & & $\bar{x} \pm s_{\bar{y}}$ & $\mathrm{~V} \%$ & Anova & $\bar{x} \pm s_{\bar{x}}$ & $\mathrm{~V} \%$ & Anova & $\bar{x} \pm s_{\bar{y}}$ & $V \%$ & Anova \\
\hline \multirow{10}{*}{ SFA } & \multirow[b]{2}{*}{ C14:0 } & & $20.55 \pm 2.04$ & 9.91 & \multirow{2}{*}{$\begin{array}{c}\mathrm{p}=0.076 \\
\mathrm{n} . \mathrm{s}\end{array}$} & $19.17 \pm 1.80$ & 18.75 & \multirow{2}{*}{$\mathrm{p}={ }_{* * *}^{1.578^{-5}}$} & $19.89 \pm 1.66$ & 16.65 & \multirow{2}{*}{$p=3.241^{\circ}$} \\
\hline & & & $37.72 \pm 5.92$ & 15.69 & & $57.45 \pm 3.31$ & 16.31 & & $88.62 \pm 6.62$ & 21.14 & \\
\hline & \multirow[b]{2}{*}{ C15:0 } & $\mathrm{M}$ & $4.30 \pm 0.15$ & 3.60 & \multirow{2}{*}{$\begin{array}{c}\mathrm{p}=0.051 \\
\text { n.s }\end{array}$} & $5.27 \pm 0.34$ & 12.86 & \multirow{2}{*}{$\mathrm{p}_{* * *}^{1.717^{-6}}$} & $6.91 \pm 0.17$ & 4.85 & \multirow{2}{*}{$p=\underset{6}{1.138^{-}}$} \\
\hline & & $\mathrm{F}$ & $6.64 \pm 0.73$ & 10.94 & & $10.62 \pm 0.34$ & 8.99 & & $17.72 \pm 0.72$ & 11.42 & \\
\hline & \multirow{2}{*}{$\mathrm{C} 16: 0$} & $\mathrm{M}$ & $217.83 \pm 9.97$ & 4.58 & \multirow{2}{*}{$\begin{array}{c}\mathrm{p}=0.061 \\
\mathrm{n} . \mathrm{s}\end{array}$} & $271.82 \pm 20.3$ & 14.94 & \multirow{2}{*}{$\begin{array}{c}\mathrm{p}=7.402^{-5} \\
* * *\end{array}$} & $340.61 \pm 6.96$ & 4.09 & \multirow{2}{*}{$p=\underset{6}{1.843^{-}}$} \\
\hline & & $\mathrm{F}$ & $408.66 \pm 62.3$ & 15.25 & & $613.57 \pm 35.4$ & 16.30 & & $879.08 \pm 37.6$ & 12.11 & \\
\hline & \multirow{2}{*}{$\mathrm{C} 17: 0$} & $\mathrm{M}$ & $5.39 \pm 3.79$ & 2.12 & \multirow{2}{*}{$\mathrm{p}=0.019$} & $7.91 \pm 0.48$ & 12.07 & \multirow{2}{*}{$\underset{* * *}{\mathrm{p}=3.235^{-7}}$} & $11.74 \pm 0.01$ & 0.18 & \multirow{2}{*}{$p=\underbrace{}_{i 1} .591^{-}$} \\
\hline & & $\mathrm{F}$ & $8.05 \pm 12.45$ & 8.14 & & $12.57 \pm 0.16$ & 3.55 & & $20.45 \pm 0.18$ & 2.53 & \\
\hline & \multirow[b]{2}{*}{ C18:0 } & $\bar{M}$ & $69.56 \pm 0.11$ & 2.45 & \multirow{2}{*}{$\mathrm{p}=0.048$} & $81.74 \pm 3.59$ & 8.77 & \multirow{2}{*}{$\mathrm{p}_{* * *}^{1.303^{-6}}$} & $96.17 \pm 1.93$ & 4.01 & \multirow{2}{*}{$p=\frac{1.377^{-}}{6}$} \\
\hline & & $\mathrm{F}$ & $95.58 \pm 0.66$ & 8.34 & & $140.54 \pm 3.61$ & 7.26 & & $216.93 \pm 8.16$ & 10.63 & \\
\hline \multirow{2}{*}{\multicolumn{2}{|c|}{ Total SFA }} & $\bar{M}$ & \multicolumn{3}{|c|}{317.63} & 385.90 & & & \multicolumn{3}{|c|}{475.31} \\
\hline & & $\mathrm{F}$ & \multicolumn{3}{|c|}{556.65} & 834.76 & & & \multicolumn{3}{|c|}{1222.79} \\
\hline \multirow{6}{*}{ MUFA } & \multirow[b]{2}{*}{ f16:1n-7 } & $\mathrm{M}$ & $26.54 \pm 1.70$ & 14.29 & & $27.50 \pm 4.01$ & 29.14 & & $26.63 \pm 3.11$ & 23.33 & $=2.1$ \\
\hline & & $\mathrm{F}$ & $61.82 \pm 7.97$ & 12.14 & n.s. & $105.74 \pm 6.56$ & 17.55 & & $173.22 \pm 10.29$ & 16.80 & $* * *$ \\
\hline & & $\bar{M}$ & $13.76 \pm 0.51$ & 3.72 & . & $16.40 \pm 0.91$ & 11.05 & $p=12$ & $22.01=0.51$ & 4.65 & $\mathrm{p}=4.348^{-8}$ \\
\hline & C18:1n-7 & $\mathrm{F}$ & $20.40 \pm 2.35$ & 11.50 & n.s. & $33.66 \pm 1.08$ & 9.08 & & $58.67 \pm 1.71$ & 8.24 & \\
\hline & & $\bar{M}$ & $207.80 \pm 12.2$ & 5.89 & & $271.09 \pm 22.5$ & 16.57 & & $328.38=9.06$ & 5.52 & $=0.122$ \\
\hline & & $\mathrm{F}$ & $359.09 \pm 45.5$ & 12.68 & & $592.60 \pm 17.9$ & 8.55 & & $949.18 \pm 38.41$ & 11.45 & \\
\hline
\end{tabular}


continuated table 8

\begin{tabular}{|c|c|c|c|c|c|c|c|c|c|c|c|}
\hline \multirow{2}{*}{\multicolumn{2}{|c|}{ Total MUFA }} & \multirow{2}{*}{\begin{tabular}{|c}
$\mathrm{M}$ \\
$\mathrm{F}$ \\
\end{tabular}} & \multirow{2}{*}{\multicolumn{3}{|c|}{$\begin{array}{l}248.09 \\
441.31\end{array}$}} & \multirow{2}{*}{\multicolumn{3}{|c|}{$\begin{array}{l}314.99 \\
731.99 \\
\end{array}$}} & \multicolumn{3}{|c|}{377.01} \\
\hline & & & & & & & & & & 81.07 & \\
\hline & 6 & $\mathrm{M}$ & $181.43 \pm 5.31$ & 2.93 & $\mathrm{p}=0.049$ & $242.59 \pm 16.2$ & 13.37 & $p=6.187^{-6}$ & $369.37 \pm 2.56$ & 1.39 & $\mathrm{p}=3.973^{-7}$ \\
\hline & 10.2 & $\mathrm{~F}$ & $257.23 \pm 23.3$ & 9.04 & & $393.42 \pm 9.48$ & 6.82 & & $680.14 \pm 18.43$ & 7.66 & \\
\hline & & $\bar{M}$ & $13.53 \pm 0.81$ & 5.99 & $=0.069$ & $20.50 \pm 2.18$ & 21.31 & $p=6$ & $33.77 \pm 0.33$ & 1.98 & $n=2.904^{-7}$ \\
\hline & C18:3n-3 & $\mathrm{F}$ & $22.72 \pm 3.10$ & 13.64 & n.s & $39.72 \pm 1.19$ & 8.47 & & $71.52 \pm 2.16$ & 8.56 & \\
\hline & & $\mathrm{M}$ & $2.85 \pm 0.06$ & 2.25 & $\mathrm{p}=0.310$ & $3.23 \pm 0.13$ & 8.21 & $1^{-4}$ & $5.38 \pm 0.05$ & 1.68 & $\mathrm{p}=3.337^{-7}$ \\
\hline & $20: 2 n-6$ & $F$ & $3.24 \pm 0.25$ & 7.70 & . & $4.78 \pm 0.17$ & 10.25 & & $8.81 \pm 0.20$ & 6.39 & \\
\hline & 520 & $\mathrm{M}$ & $3.94 \pm 0.13$ & 3.38 & $\mathrm{p}=0.076$ & $4.54 \pm 0.15$ & 6.55 & $\mathrm{p}=0.024$ & $4.27 \pm 0.01$ & 0.63 & $p=0.854$ \\
\hline & 20 & $F$ & $3.48 \pm 0.15$ & 4.23 & n.s & $4.17 \pm 0.07$ & 4.55 & & $4.34 \pm 0.25$ & 16.34 & n.s. \\
\hline & & $\mathrm{M}$ & $51.04 \pm 0.36$ & 0.70 & $p$ & $48.82 \pm 0.96$ & 3.93 & & $49.47 \pm 0.20$ & 0.79 & $\mathrm{p}=$ \\
\hline PUFA & $20: 4 n-6$ & $\mathrm{~F}$ & $55.16 \pm 1.06$ & 1.91 & $\mathbf{p}$ & $54.69 \pm 1.44$ & 7.45 & & $53.69 \pm 2.22$ & 11.72 & n.s \\
\hline & & $\mathrm{M}$ & $10.42 \pm 0.36$ & 3.47 & $\mathrm{p}=0.240$ & $11.21 \pm 0.35$ & 6.27 & $\mathrm{p}=0$ & $10.66 \pm 0.14$ & 2.69 & $\mathrm{p}=0$. \\
\hline & C20:5n-3 & $F$ & $9.40 \pm 0.54$ & 5.77 & n.s. & $10.44 \pm 0.55$ & 15.00 & 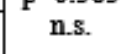 & $10.17 \pm 1.26$ & 35.16 & n.s \\
\hline & the & $\mathrm{M}$ & $14.86 \pm 0.10$ & 0.65 & $\mathrm{p}=0.008$ & $15.44 \pm 0.11$ & 1.39 & $\mathrm{p}=1.80 \mathrm{8}^{-5}$ & $15.38 \pm 0.01$ & 0.08 & $p=0.006$ \\
\hline & -22 & $F$ & $14.25 \pm 0.12$ & 0.83 & & $14.30 \pm 0.09$ & 1.80 & & $14.46 \pm 0.18$ & 3.54 & \\
\hline & & $\mathrm{M}$ & $8.39 \pm 0.14$ & 1.65 & $\mathrm{p}=0.526$ & $6.91 \pm 0.16$ & 4.66 & & $6.79 \pm 0.07$ & 2.09 & $p=0$ \\
\hline & C22:5n-3 & $\mathrm{F}$ & $8.66 \pm 0.28$ & 3.24 & n.s & $8.37 \pm 0.36$ & 12.14 & & $6.92 \pm 0.47$ & 19.04 & $n=$ \\
\hline & $\mathrm{C} 22: 6 \mathrm{n}-3$ & $\mathrm{M}$ & $23.79 \pm 0.42$ & 1.76 & $\mathrm{p}=0.833$ & $21.13 \pm 1.10$ & 10.43 & $\mathrm{p}=0.115$ & $22.14 \pm 0.60$ & 5.44 & $p=0.922$ \\
\hline & & $F$ & $23.44 \pm 1.09$ & 4.63 & n.s & $24.13 \pm 1.09$ & 12.74 & n.s & $22.32 \pm 1.27$ & 16.15 & n.s \\
\hline Total & PUFA & $\mathrm{M}$ & & 310. & & & 74.36 & & & & \\
\hline & & $F$ & & 397. & & & 54.02 & & & 872 . & \\
\hline PUF & A:SFA & $\mathrm{M}$ & & 0.9 & & & 0.970 & & & 1.0 & \\
\hline
\end{tabular}

Pla, 2008, [6, 41, 48] found higher PUFA:SFA ratio for rabbit meat obtained in ecological system compared to the conventional system ( 0.7 vs. 0.5$)$, underlining the former one better nutritional quality. The PUFA:SFA ratio from the current study exceeds, on average, even the one reported in the previous study for ecologically produced rabbit meat [48]. Therefore, the nutritive-biological value of rabbit meat from the Flemish Giant breed could be considered higher.

The latest studies focus the genetic selection of the rabbits to increase the intramuscular fat deposition (for at least six generations), leading to increasing the MUFAs and decreasing PUFAs, while no variations were induced in SFAs levels [33-48, 59, 64-66]. Other research trends intend to increase the oxidation stability of PUFAs by adding natural herb extracts and vitamin $E$ in rabbit feed $[15,16,58,60]$ willing to extend the shelf life, by avoiding the rancidity of lipids $[7,28]$.

\section{Conclusions}

The results obtained from the sensory analysis were relatively close as score for the three muscle groups taken into study. The $\mathrm{pH}$ value was higher for TB muscles. The assessments indicated the highest proportion of proteins in LD muscles coming from males (21.70\%), the highest lipid content in the TB muscles of females $(2.65 \%)$, and the amount of fatty acids for all analyzed muscle groups had higher values in females, with a favorable PUFA: MUFA ratio; water had higher values in LD and SM muscles compared to TB muscles (in relation with the higher fat content and their higher energy value, respectively). We recommend consumption of rabbit meat, due to its high percentage of proteins, of unsaturated fatty acids, minerals, and to its relatively low energy value, compared to other species.

\section{References}

1.ARINO, B., HERNANDEZ, P., BLASCO, A., Meat Scie., 73, 2006, p.
2.ARINO, B., HERNANDEZ, P., PLA, M., BLASCO, A., Meat Scie., 75, no. 3, 2007, p. 494.

3.LI, S., ZENG, W., LI, R., HOFFMAN, L.C., HE, Z., SUN, Q., LI, H., Meat Sci., 145, 2018, p. 320.

4.NIK RAIKHAN, N.H., KHAIRUL IZWAN, A.R., International J ournal of Conservation Science, 8, no. 3, 2017, p. 537.

5.FAOSTAT (2016). Retrieved from http://www.fao.org/faostat/en/\#data/ QL.

6.LAN, Y., SHANG, Y., SONG, Y., DONG, Q., Meat Sci., 117, 2016, p. 173. 7.DELGADO, R., NICODEMUS, N., ABAD-GUAMAN, R., SASTRE, J ., MENOYO, D., CARABAÑO, R., GARCÍA, J., Animal Feed Sci. and Techn., 239, 2018, p. 44.

8.MATTIOLI, S., MACHADO DUARTE, J.M., CASTELLINI C., D'AMATO R., REGNI L., PROIETTI, P., BUSINELLI, D., COTOZZOLO, E., RODRIGUES, M., DAL BOSCO, A., Meat Sci., 143, 2018, p. 230.

9.MATTIOLI S, DAL BOSCO, A., SZENDRO, ZS., CULLERE, M., GERENCSER, Z., MATICS Z., CASTELLINI, C., DALLE ZOTTE, A., Meat Sci., 121, 2016, p. 238.

10.DELMAS, D., OUHAYOUN, J., Viandes et Produits Carnés, 11, no. 1, 1990, p.11.

11.HULOT, F., OUHAYON, J., World Rabbit Sci., 7, 1999, p. 15.

12.BADR, H.M., Meat Sci., 67, 2004, p. 541.

13.BAVIERA-PUIG, A., BUITRAGO-VERA, J., ESCRIBA-PEREZ, C., MONTERO-VICENTE, L., World Rabbit Sci., 25, 2017, p. 95.

14.BIANCHI, M., PETRACCI, M., CAVANI, C., World Rabbit Scie., 17, 2009, p. 97.

15.CARDINALI, R., CULLERE, M., DAL BOSCO, A., MUGNAI, C., RUGGERI, S., MATTIOLI, S., DALLE ZOTTE, A., Livestock Sci., 17, 2015, p. 83.

16.CASTELLINI, C., DAL BOSCO, A., BERNARDINI, M., CYRIL, H.W., Meat Sci., 50, 1998, p. 153.

17.COMBES, S., POSTOLLEC, G., CAUQUIL, L., GIDENNE, T., Animal, 4, 2010, p. 295.

18.COMBES, S., INRA Prod. Anim., 17 no 5, 2004, p. 373.

19.COMBES, S., DALLE ZOTTE, A., Journ. Rech. Cuni., 2005, p.167180. 
20.COMBES, S., GONZALEZ, I, DEJ EAN, S., BACCINI, A.J EHL, N, JUIN, H.,CAUQUIL, L., GABINAUD, B., LEBAS, F., LARZUL, C., Meat Sci., 80, 2008, p. 835.

21.CORINO C., PASTORELLI G., PANTALEO L., ORIANI, G., SALVATORI G., Meat Sci., 52, 1999, p. 285.

22.CORINO, C., MOUROT, J., MAGNI, S., PASTORELLI, G., ROSI, F., J ournal of Animal Sci., 80, 2002, p. 1020.

23.CORINO, C., FILETTI, F., GAMBACORTA, M., MANCHISI, A., MAGNI, S., PASTORELLI G., ROSSI, R., MAIORANO G., Meat Sci., 66, 2003, p. 97.

24.CULLEE M., DALLE ZOTTE A., Meat Sci., 143, 2018, p. 137.

25.D'AGATA M., PREZIUSO G., RUSSO C., DALLE ZOTTE, A., MOURVAKI

E., PACl G., Meat Sci., 83, 2009, p. 691.

26.DAL BOSCO, A., CASTELLINI, C., BIANCHI, L., MUGNAI, C. Meat Scie., 66, 2004, 407.

27.DAL BOSCO, A., GERENCER, ZS., SZENDRO, ZS., MUGNAI, C., CULLERE, M., KOVaCS, M., DALLE ZOTTE, A., Meat Sci., 96, 2014, p. 114.

28.DAL BOSCO, A., MATTIOLI, S., CULLERE, M., SZENDRO, ZS., GERENCSER, ZS., MATICS, ZS., CASTELLINI, C., SZIN, M., DALLE ZOTTE, A., Meat Sci., 143, 2018, p.46.

29.DALLE ZOTTE, A., Livestock Science, 75, 2002 p. 11.

30.DALLE ZOTTE, A., CELIA, C., SZENDRo, ZS., Livestock Sci., 189 , 2016, p. 82.

31.DALLE ZOTTE, A., CULLERE, M., REMIGNON, H., ALBERGHINI, L., PACl, G. World Rabbit Sci., 24, 2016, p. 145.

32.DALLE ZOTTE, A., CULLERE, M., SARTORI, A., DAL BOSCO, A., GERENCSeR, Z., MATICS, Z., SZENDRO, Z., World Rabbit Scie., 22, 2014, p. 11.

33.DALLE ZOTTE, A., PRINCZ, Z., METZGER, S., SZABO, A., RADNAI, I., BIRO-NEMETH, E., SZENDRO, Z., Livestock SCi., 122, 2009, p. 39. 34.DALLE ZOTTE, A., SZENDRO, K., GERENCSER, Z., SZENDRO, Z., CULLERE, M., ODERMATT, M., MATICS, Z., Meat Sci., 110, 2015. p. 126. 35.DALLE ZOTTE, A., SZENDRO, Z., Meat Sci., 88, 2011, p. 319.

36.CULLERE, M., DALLE ZOTTE, A., TASONIERO, G., GIACCONE, V., SZENDRO, Z., SZIN, M., ODERMATT, M., GERENCSER, Z., DAL BOSCO,

A., MATICS, Z., Meat Sci, 141, 2018, p. 36.

37.KOUBA, M., BENATMANE, F., BLOCHET, J.E., MOUROT, J., Meat Sci., 80, 2008, p. 829.

38.LOPONTE, R., SECCI, G., MANCINI, S., BOVERA, F., PANETTIERIA, V., NIZZADA., DI MEOA C., PICCOLOAG., PARISI G., Meat Sci., 145, 2018, p. 137.

39.LISTE, G., VILLAROEL, M., CHACON, G., SANUDO, C., OLLETA, J.L., GARCIA-BELENGUER S., Meat Sci., 82, 2009, p. 71.

40.MARTINO M., MATTIOLI S., FARKAS P., SZENDRO ZS., DAL BOSCO A., RUGGERI S., MATICS ZS., CASTELLINI C., GERENCSER ZS., World Rabbit Sci. 2016, 24, p. 129.

41.MARTINEZ-ÁLVARO, M., HERNANDEZ, P., BLASCO, A.J ., Anim. Sci., 94, 2016, p. 4993.

42.MARTINEZ-ALVARO M., PENALBA, V., BLASCO, A., HERNANDEZ,

P.) . Anim. Sci., 94, 2016, p. 5137.

43.MARTINEZ-ALVARO, M., HERNANDEZ, P., AGHA, S., BLASCO, A., Meat Sci., 139, 2018, p. 187-191.

44.MARTINEZ-ALVARO, M., HERNANDEZ, P., World Rabbit Sci. 26, 2018, p. 43.

45.PACl, G., PREZIUSO, G., D'AGATA, M., RUSSO, C., DALLE ZOTTE, A. Meat Sci., 93, 2013, p. 162.

46.PEIRETTI, P. G., MEINERI, G. Meat Sci., 80, 2008, p. 1116.

47.PETRACCI, M., CAVANI, C., World Rabbit Sci., 21, 2013, p. 217.

48.PLA M., Livestock Sci., 115, 2008, p. 1.

49.VOLEK, Z., BURES, D., UHLIROVA, L., Meat Sci., 141, 2018, p. 50. 50.GONDRET F., LARZUL C., COMBES S., ROCHAMBEAU H., J our. Ani. Sci., 83, 2005, p. 1526.

51.GONDRET, F., COMBES, S., LEFAUCHEUR L., LEBRET B., Reprod. Nutr. Dev., 45, 2005, p. 86.

52.HERMIDA, M., GAONZALES, M., MIRANDA, M., RODRIGUEZ-OTERO, J.L., Meat Sci., 73, 2006, p. 635.

53.HERNANDEZ, P., Revista científica de nutrición. 154, no 8, 2007, p. 33.
54.HERNANDEZ, P., CESARI, V., PLA, M., Intern. Congress of Meat Sci. and Tech., 2007, p. 367.

55.HERNANDEZ, P., CESARI, V., BLASCO A., Meat Sci., 78, 2008, p. 485. 56.CARDINALI, R., CULLERE, M., DAL BOSCO, A., MUGNAI, C., RUGGERI, S., MATTIOLI, S., CASTELLINI, C., TRABALZA-MARINUCCI, M., DALLEZOTTE, A. Livestock Scie., 175, 2015, p. 83.

57. LAMBERTINI, L., VIGNOLA, G., BADIANI, A., ZAGHINI, G., FORMIGONI, A., Meat Scie., 72, 2006, p. 641.

58.LARZUL, C., THEBAULT, R. G., ALLAIN, D., Meat Science, 67, no. 3, 2004, p. 479.

59.LARZUL, C., GONDRET, F., INRA Prod. Anim., 18, no. 2, 2005, p. 119.

60.LIU HUA WEI, GAI F., GASCO L., BRUGIAPAGLIA A., LUSSIANA C., GUO K. J., TONG J.M., ZACCARATO I., Meat Scie., 83, 2009, p. 678.

61.MAZZONE G., VIGNOLA G., GIAMMARCO M., MANETTA A. C., LAMBERTINI L., Meat Scie., 85, 2010, p. 33.

62.VALENZUELA, C., DE ROMANA, D.L., SCHMIEDE, C., MORALES, M.S., OLIVARES, M., PIZARRO, F., Biological Trace Element Research, 143 no 3, 2011, p. 1489.

63.XICCATO, G., PARIGI-BINI, R., DALLE-ZOTTE, A., CARAZZOLO, A. Proc. 40th Internat. Congress of Meat Scie. and Tech., 1994, p. 52.

64.ZOMENO, C., HERNANDEZ, P., BLASCO, A., World Rabbit Scie., 19, no. 4, 2011, 203.

65.ZOMENO, C., HERNANDEZ, P., BLASCO, A., Journal of Ani. Scie., 91, no. 9, 2013, p. 4526.

66.ZOMENO, C., JUSTE, V., \& HERNANDEZ, P., Meat Scie., 91, no. 2, 2012, p. 155.

67.POP, C., MURESAN, G., POP, I.M., Quality, safety and food products merceology. Publisher: The Science Book Home, Cluj-Napoca, 2013, p. 295.

68.BAZAN N. G., MOLINA M. F., GORDON, W.C., Ann. Rev. of Nutrit., 31, 2011, p. 321.

69.RIEDIGER, N.D., OTHMAN, R.A., SUH, M., MOGHADASIAN, M.H., Journal of the American Dietetic Assoc., 109, no. 4, 2009, p. 668.

70.SARAVANAN, P., DAVIDSON, N.C., SCHMIDT, E.B., CALDER, P.C., 376, no. 9740, 2010, p. 540.

71.WALL, R., ROSS, R. P., FITZGERALD, G. F., STANTON, C., Nutrit. Rev., 68, no. 5, 2010, p. 280.

72. MIERLITA, D., SIMEANU, D., POP, I.M., CRISTE, F., POP, C., SIMEANU, C., LUP, F., Rev. Chim. (Bucharest), 69, no. 2, 2018, p. 453. 73. MIERLITA, D., POP, I.M., LUP, F., SIMEANU, D., VICAS, S.I., SIMEANU, C., Rev. Chim. (Bucharest), 69, no. 1, 2018, p. 160.

74. IOSIF, L., GAMAN, L., CRIHANA, I., KOVACS, E., STOIAN, I., LUPESCU, 0., Rev. Chim. (Bucharest), 67, no. 12, 2016, p. 2638.

75. TOCIU, M., TODASCA, M.C., STANESCU, M.D., Rev. Chim. (Bucharest), 68, no. 9, 2017, p. 2002.

76. POP, F., GIURGIULESCU, L., DUMUTA, A., VOSGAN, Z., Rev. Chim. (Bucharest), 64, no. 11, 2013, p. 1372.

77. COBZARU, C., APOSTOLESCU, N., APOSTOLESCU, G.A., MARINOIU, A., SILION, M., CERNATESCU, C., Rev. Chim. (Bucharest), 67, no. 4, 2016, p. 724.

78. DUMITRU, M.G., Rev. Chim. (Bucharest), 67, no.6, 2016, p. 1127. 79. PAPUC, C., CRIVINEANU, M., NICORESCU, V., PAPUC, C., PREDESCU, C., Rev. Chim. (Bucharest), 63, no. 12, 2012, p. 1198. 80. LINGVAY, I., BUDRUGEAC, P., VOINA, A., CUCOS, A., MOSCALIUC, H., Rev. Chim. (Bucharest), 67, no. 11, 2016, p. 2202.

81. COPOLOVICI, D., BUNGAU, S., BOSCENCU, R., TIT, D.M., COPOLOVICI, L., Rev. Chim. (Bucharest), 68, no. 3, 2017, p. 507. 82.SIMOPOULOS A.P., The American J ournal of Clinical Nutrit., 6 , 2002, p. 495.

83.LUP, F., POP, I.M., SIMEANU, D., VICAS, S., SIMEANU, C., MIERLITA, D., Rev. Chim. (Bucharest), 69, no. 1, 2018, p. 222.

84.SIMEANU, C., SIMEANU, D., POPA, A., USTUROI, A., BODESCU, D., DOLIS, M.G., Rev. Chim. (Bucharest), 68, no. 5, 2017, p. 1063.

85.SIMEANU, C.; SIMEANU, D., DOLIS, M. G., Res. J ournal of Biotech., 12, no. 2, 2017, p. 7.

86. *** AOAC, Official Methods of Analysis of the AOAC. $15^{\text {th }}$ ed., Association of Official Analytical Chemists, Arlington, VA, 1990, USA.

Manuscript received: 21.07 .2018 